\title{
A case series of a pav+ weaning protocol in an acute care environment demonstrating an absence of weaning failure
}

\author{
E Rohrs $^{1 *}$, S Reynolds ${ }^{1,2,3}$, J Zurba ${ }^{1}$ \\ From ESICM LIVES 2015 \\ Berlin, Germany. 3-7 October 2015
}

\section{Introduction}

Most patients undergoing mechanical ventilation (MV) in critical care units are liberated from the ventilator within a median of 7 days. Unfortunately, some patients experience difficulty in liberation from MV during their ICU stays and require extended time on MV. It has been estimated that $40 \%$ of the patient's duration on the ventilator is spent weaning.[1] Moreover, although patients requiring prolonged mechanical ventilation represent approximately $6 \%$ of all ventilated patients, they consume $37 \%$ of intensive care unit resources. [2] Therefore, accelerating the liberation of prolonged weaning patients from MV improves patient care and could yield significant economic benefits.

Table 1 Clinical Parameters of Wean Group vs. Literature.

\begin{tabular}{|c|c|c|c|c|c|c|c|c|}
\hline & $\begin{array}{l}\text { PAV + } \\
\text { Cohort } \\
(n=40)\end{array}$ & $\begin{array}{l}\text { Rose } 2012(5) \\
(n=115)\end{array}$ & $\begin{array}{l}\text { Schönhofer } \\
2002(6) \\
(n=403)\end{array}$ & $\begin{array}{l}\text { Jubran } \\
2013 a(7) \\
(n=152)\end{array}$ & $\begin{array}{l}\text { Jubran } \\
2013 b(7) \\
(n=160)\end{array}$ & $\begin{array}{l}\text { Pilcher } \\
2005(8) \\
(n=153)\end{array}$ & $\begin{array}{l}\text { Scheinhorn } \\
2002 \mathrm{a}(9) \\
(\mathrm{n}=252)\end{array}$ & $\begin{array}{l}\text { Scheinhorn } \\
2002 b(9) \\
(n=238)\end{array}$ \\
\hline $\begin{array}{l}\text { Age (years) median } \\
(\mathrm{IQR})^{*}\end{array}$ & $\begin{array}{l}69(60.5- \\
74.3)\end{array}$ & $70(59-77)$ & $66.0(58.2-71.6)$ & $70(62-79)$ & $70(63-77)$ & $70(63-77)$ & 73 & 71 \\
\hline Female Gender & $48.00 \%$ & $49.60 \%$ & $35.50 \%$ & $42 \%$ & $50 \%$ & $52 \%$ & & \\
\hline BMI & $\begin{array}{l}25.55(20.3- \\
31)\end{array}$ & & $23.1(19.6-27.6)$ & & & & & \\
\hline $\begin{array}{l}\text { APACHE } \| \text { at } \\
\text { admission }\end{array}$ & $24(17.8-28)$ & $11.9(+/-4.1)^{*}$ & & $15(13-19)^{*}$ & $15(14-15)^{*}$ & $15(10-20)$ & & \\
\hline $\begin{array}{l}\text { SOFA at ICU } \\
\text { Admission }\end{array}$ & $9(8-12)$ & & & $41(30-62)$ & & & & \\
\hline $\begin{array}{l}\text { Length of Hospital } \\
\text { Stay (days) median } \\
\text { (IQR) }\end{array}$ & $\begin{array}{l}68(44.3- \\
105)\end{array}$ & & & $39 / 152(26 \%)$ & $42(28-63)$ & & 42.5 & 49 \\
\hline In hospital Mortality & $\begin{array}{l}15 / 40 \\
(38 \%)\end{array}$ & & $\begin{array}{l}98 / 403( \\
24.3 \%)\end{array}$ & $14.50 \%$ & $41 / 160(26 \%)$ & $\begin{array}{l}42 / 153 \\
(27 \%)\end{array}$ & & \\
\hline $\begin{array}{l}\text { Death during } \\
\text { Weaning }\end{array}$ & $4 / 40(10 \%)$ & $13 \%$ & $24.30 \%$ & $14.50 \%$ & $10 \%$ & $26.10 \%$ & $30.70 \%$ & \\
\hline $\begin{array}{l}\text { Weaning Failure- } \\
\text { Ventilatory } \\
\text { Dependance }\end{array}$ & 0 & $33.90 \%$ & $19.00 \%$ & $40.80 \%$ & $36.90 \%$ & $34.60 \%$ & $17.90 \%$ & $10.90 \%$ \\
\hline
\end{tabular}

${ }^{1}$ Fraser Health Authority, New Westminster, Canada

Full list of author information is available at the end of the article

(C) 2015 Rohrs et al.; This is an Open Access article distributed under the terms of the Creative Commons Attribution License (http:// creativecommons.org/licenses/by/4.0), which permits unrestricted use, distribution, and reproduction in any medium, provided the original work is properly cited. 


\section{Rationale}

Which weaning strategy is "best" is controversial. Proportional Assist Ventilation (PAV+) has many aspects that are theoretically beneficial as part of a difficult weaning protocol.

\section{Methods}

Single center case series of patients undergoing a PAV+ protocolized wean from an 18 bed mixed medical/surgical/ trauma Canadian tertiary care ICU.

\section{Results}

Over the 39 month (3.25 year) period 46 patients underwent a slow wean, 40 of whom spent greater than $70 \%$ of their time weaning in a PAV+ mode. During weaning from MV there were $4 / 40$ (10\%) deaths in the PAV+ group, despite a high admitting APACHE II score. All patients in the PAV+ group who survived were successfully weaned from MV over a median of 13.3 (9.2-20) days.

\section{Conclusions}

Although this study was conducted in an acute hospital context that is significantly different from Long Term Acute Care Hospitals, it raises the possibility that a PAV+ weaning protocol could be superior to PSV or $t$ piece weaning strategies. Further studies are needed.

\section{Grant Acknowledgment}

Study funded by grant from Covidien.

\section{Authors' details}

${ }^{1}$ Fraser Health Authority, New Westminster, Canada. ${ }^{2}$ University of British Columbia, Vancouver, Canada. ${ }^{3}$ Department of Critical Care Medicine, Royal Columbian Hospital, New Westminster, Canada.

Published: 1 October 2015

\section{References}

1. Esteban A, et al: Evolution of MV in response to clinical research. Am J Respir Crit Care Med 2008, 177:170-177.

2. Boles JM, et al: Weaning from MV. Eur Respir J 2007, 29:1033-1056.

3. Rose L, Fraser IM: Patient characteristics and outcomes of a provincial prolonged-ventilation weaning centre: A retrospective cohort study. Can Respir J 2012, 19:216-220.

4. Schonhofer $B$, et al: Survival of mechanically ventilated patients admitted to a specialised weaning centre. Intensive Care Med 2002, 28:908-916.

5. Jubran A, et al: Effect of pressure support vs unassisted breathing through a tracheostomy collar on weaning duration in patients requiring prolonged mechanical ventilation: $A$ randomized trial. JAMA 2013, 309:671-677.

6. Pilcher DV, et al: Outcomes, cost and long term survival of patients referred to a regional weaning centre. Thorax 2005, 60:187-192.

7. Scheinhorn DJ, et al: Liberation from prolonged mechanical ventilation. Crit Care Clin 2002, 18:569-595.

8. Penuelas OF, et al: Characteristics and outcomes of ventilated patients according to time to liberation from MV. Am J Respir Crit Care Med 2011 184:430-437.
doi:10.1186/2197-425X-3-S1-A1008

Cite this article as: Rohrs et al:: A case series of a pav+ weaning protocol in an acute care environment demonstrating an absence of weaning failure. Intensive Care Medicine Experimental 2015 3(Suppl 1):A1008.

\section{Submit your manuscript to a SpringerOpen ${ }^{\mathcal{D}}$ journal and benefit from:}

- Convenient online submission

- Rigorous peer review

- Immediate publication on acceptance

- Open access: articles freely available online

- High visibility within the field

- Retaining the copyright to your article

Submit your next manuscript at $>$ springeropen.com 